\title{
Physiological responses of anti-predation in prey fish to the threat of piscivorous fish in different underwater visibility conditions
}

\author{
Leandro Fabrício Fiori' (D), Bruno R. S. Figueiredo',2 (D), Audrei Pavanello3 (D), Vander Silva Alves ${ }^{3}$ (D), \\ Paulo Cezar de Freitas Mathias,3 (D) \& Evanilde Benedito',2 (D)
}

\begin{abstract}
1. Programa de Pós-Graduação em Ecologia de Ambientes Aquáticos Continentais (PEA)/Núcleo de Pesquisas em Limnologia, Ictiologia e Aquicultura (Nupélia) da Universidade Estadual de Maringá (UEM). Av. Colombo, 5790, 87020-900 Maringá, PR, Brasil. (leandrofiori_8@hotmail.com)

2.Departamento de Biologia, Universidade Estadual de Maringá (UEM). Av. Colombo, 5790, 87020-900 Maringá, PR, Brasil.

3. Laboratório de Biologia Celular da Secreção, Departamento de Biotecnologia, Genética e Biologia Celular, Universidade Estadual de Maringá (UEM), Av. Colombo, 5790, 87020-900 Maringá, PR, Brasil.
\end{abstract}

Received 8 January 2018

Accepted 11 July 2018

Published 08 October 2018

DOI 10.1590/1678-4766e2018032

ABSTRACT. Considering that the anti-predation behaviour of prey fishes may vary with predator hunting strategy, we experimentally investigated the physiological responses of Astyanax bimaculatus (Linnaeus, 1758) shoals to the presence of two piscivorous fish species with different hunting modes: sit-and-wait and active pursuit. In addition, we evaluated the influence of underwater visibility conditions on the interaction between predator and prey. We tested the hypotheses that: (i) prey plasma cortisol and glucose levels vary according to piscivore hunting strategy, and (ii) no reduction in plasma glucose and cortisol levels takes place in turbid environments due to the inability of prey to accurately recognise predators by non-visual signals. The results revealed that the presence of piscivorous fish increased plasma cortisol levels in prey, with no significant difference recorded between the two hunting strategy treatments. We also observed no significant change in plasma glucose levels in different water transparency conditions. Thus, we conclude that physiological changes in the selected prey fish do not vary with predator hunting mode, and it is therefore necessary to consider the ability of the prey to recognise and evaluate danger, regardless of piscivore hunting strategy.

KEYWORDS. Metabolism, Hoplias aff. malabaricus, Astronotus crassipinnis, Astyanax bimaculatus, turbidity.

RESUMO. Respostas fisiológicas de anti-predação em peixes-presas sobre a ameaça de piscívoros em diferentes condições de visibilidade subaquática. Considerando que o comportamento de anti-predação de peixes-presas podem variar de acordo com a estratégia de caça de predadores, investigaram-se experimentalmente as respostas fisiológicas de cardumes de Astyanax bimaculatus (Linnaeus, 1758) na presença de duas espécies de peixes piscívoros com diferentes modos de caça: senta-espera e busca ativa. Além disso, avaliou-se a influência das condições de visibilidade subaquática sobre a interação entre predadores e presas. Para isso, realizou-se um experimento para testar as hipóteses de que (i) os níveis plasmáticos de cortisol e glicose variam de acordo com a estratégia de caça dos peixes piscívoros, e (ii) em ambiente com elevada turbidez não haverá redução nos níveis plasmáticos de glicose e cortisol devido à incapacidade da presa em reconhecer com precisão os predadores através de estímulos não visuais. Os resultados evidenciam que a presença de peixes piscívoros aumenta os níveis plasmáticos de cortisol das presas, mas não houve diferença significativa entre os tratamentos com piscívoros de diferentes estratégias de caça. Não foi observada alteração significativa nos níveis de glicose plasmática entre tratamentos com água transparente e água túrbida. Assim, conclui-se que as mudanças fisiológicas na espécie de peixes-presa utilizada não variam com o modo de caça do predador e é, portanto, necessário considerar a habilidade das presas de reconhecer e avaliar a ameaça de predação, independentemente da estratégia de caça do piscívoro.

PALAVRAS-CHAVE. Metabolismo, Hoplias aff. malabaricus, Astronotus crassipinnis, Astyanax bimaculatus, turbidez.

Predation is an important shaping force in prey populations and provides stability to fish communities (LIMA \& Dill, 1990; LinK \& GARRISON, 2002; MoustahFid et al., 2010). Besides the direct effect of predation (consumptive effects), indirect effects (non-consumptive effects) also occur as a result of changes in behaviour that prey employ to reduce their risk of mortality (LIMA, 1998; WERNER \& PEACOR, 2006; Hoeinghaus \& Pelicice, 2010). Behavioural responses of anti-predation in fish include reducing swimming activity, staying in a vigilant state and increasing the time spent in refuges (Kovalenko et al., 2010; Hoeinghaus \& Pelicice, 2010; AJEMIAN et al., 2015). Changes may also be observed in the form of altered physiological traits, such as increases in blood glycemia and cortisolemia, which may be detected in fish after they face some form of stress, such as an encounter with predators (BELL et al., 2007).

Blood cortisol and glucose levels are efficient indicators used in fish to detect physiological changes caused by stress (MARTíNEZ-PORCHAS et al., 2009). Whereas cortisol changes are mostly regarded as a primary response, variation in glucose is considered a secondary response (BARTON, 2002). The primary response is caused by neuroendocrine changes, activated by the sympathetic nervous system releasing catecholamines (adrenaline and noradrenaline) from chromaffin 
tissue into the bloodstream. As part of this primary response the hypothalamic-pituitary-interrenal axis is activated, resulting in increased plasma levels of glucocorticoids such as cortisol. Secondary responses are associated with metabolic alterations, such as increased blood glucose and lactic acid levels, as well as hyperventilation and other effects (BARTON \& IWAMA, 1991; REID et al., 1998; BARTON, 2002). If primary and secondary responses persist chronically, tertiary responses may occur that are associated with deleterious effects, including a reduced growth rate, a reduction in the activity or efficiency of the immune system (immunosuppression) and the inhibition of reproduction (BARTON, 2002).

Among the various studies dedicated to the analysis of physiological changes caused by stress in fish, the majority focus on species of economic interest, such as tilapia Oreochromis niloticus Linnaeus, 1758 (BARRETO \& VolPATO, 2006; SANCHES et al., 2015), trout - Salmo trutta Linnaeus, 1758 (RuANe et al., 1999; FlodMARK et al., 2002), matrinxã - Brycon amazonicus Günther, 1869 (HoshiBa et al., 2009; BENDHACK \& URBINATI, 2009) and jundiá - Rhamdia quelen Quoy \& Gaimard, 1824 (BARCELlos et al., 2001; KOAKOSKI et al., 2012). Most stressor reviews are associated with catch, transport and climate change (MARTínez-PoRCHAS et al., 2009), with considerably fewer dedicated to investigating the physiological changes caused by ecological relationships, such as the threat of predation on prey.

When fish exhibit anti-predation behaviour after the perception of a threat, the stress may induce an increase in plasma cortisol and glucose levels (ReHNBERG et al., 1987; MARTínez-Porchas et al., 2009). However, anti-predation behaviour may vary according to the hunting modes of piscivorous fish, which can influence habitat use by prey (Peckarsky \& McIntosh, 1998; Guariento et al., 2014). Thus, it could be expected that plasma cortisol and glucose levels also change according to the type of stress caused by different predator hunting modes.

Several species of fish primarily use vision to detect nearby predation threats (FERRARI et al., 2010; KOVALENKO et al., 2010; BECKER \& GABOR, 2012). However, aquatic environments often exhibit high turbidity and consequently low underwater visibility (DE RoBERTis et al., 2003). Although turbidity provides a visual refuge for prey, making them less noticeable to predators, it also decreases their distance of reaction to predator presence (RANÅKER et al., 2012; FigueIREDo et al., 2016). Turbidity is predicted to be more frequent as a result of climate change (TRENBERTH et al., 2007; THOMPSON et al., 2013). On the other hand, oligotrophic rivers with clear waters are also increasing as a result of dam construction, which leads to the retention of nutrients and suspended solids upstream (RoBERTo et al., 2009). In either case, underwater visibility is an important mediator of predator-prey interaction, and may be even more important in future environmental scenarios.

Here, we experimentally investigated the physiological responses of Astyanax bimaculatus (Linnaeus, 1758) shoals in both the absence of predators and the presence of two piscivores with different hunting modes of sit-and-wait
[Hoplias aff. malabaricus (Bloch, 1794)] and active pursuit [Astronotus crassipinnis (Heckel, 1840)]. Predator-prey interaction was investigated under two different conditions of underwater visibility (clear vs turbid water). We predicted that prey plasma cortisol and glucose levels would be highest in the presence of piscivores, but would vary depending on predator hunting strategy. We also predicted that such physiological changes would be higher in clear than in turbid water due to the reduced ability of prey to accurately recognise predators based on non-visual cues.

\section{MATERIAL \& METHODS}

Experimental design. We used shoals of $A$. bimaculatus (total length [TL] $5.0 \pm 0.54 \mathrm{~cm}$ ) as prey to investigate their plasma cortisol and glucose levels in three different predator regime treatments: absence of piscivores and presence of piscivores with distinct hunting modes of sit-and-wait ( $H$. aff. malabaricus - TL $18.2 \pm 0.65 \mathrm{~cm}$ ) and active pursuit (A. crassipinnis - TL $17.6 \pm 3.90 \mathrm{~cm})$. Interaction between prey and each predation type was investigated in clear and turbid water treatments. Therefore, our experimental design was conceived to test the effects of two factors ('predator regime', three levels; 'turbidity', two levels) on two response variables (plasma cortisol and glucose levels), resulting in a total of six treatment combinations, each of which were replicated six times. We conducted the experiments in mesocosms, using rectangular aquariums as experimental units (water volume $35 \mathrm{l}$; width $=25 \mathrm{~cm}$; length $=45 \mathrm{~cm}$; height $=35 \mathrm{~cm}$ ) containing clear or turbid water.

Hoplias aff. malabaricus is native to the upper Paraná River floodplain and inhabits mainly lake environments (Petry et al., 2010), where they act as a sit-and-wait predator (Montenegro et al., 2013). In contrast, A. crassipinnis is an exotic fish introduced by aquarists in lakes connected to the Paraná River floodplain (ABUJANRA et al., 2009; Julio $\mathrm{J}_{\mathrm{R}}$ et al., 2009), where they actively pursue their prey. Astyanax bimaculatus was chosen due to its high abundance in the upper Paraná River floodplain and because it is an important item in the piscivorous diet (GEALH \& HAHN, 1998; HaHn et al., 2004).

Piscivores were collected in September 2015 by angling in aquatic environments connected to the Parana River. Following transport to the laboratory, all animals were treated with a fungicide and bactericide solution to prevent infection before the experimental period. Prey $(A$. bimaculatus) was obtained from a commercial fish farm registered with the local competent environmental authority. As the prey had not coexisted with any predators during their lives, a period of coexistence was therefore required for the prey to learn to recognise the predation threat and defend themselves (Lima \& Dill, 1990; Brown, 2003; FERRARI et al., 2008). To minimise this issue, before the beginning of the experiments we provided such a period of coexistence among predators and prey. This recognition period consisted of keeping the shoal of $450 \mathrm{~A}$. bimaculatus (young) together 
with $H$. aff. malabaricus and $A$. crassipinnis in a 10001 tank, also containing aquatic plants, for 24 hours. During this period, $14 \mathrm{~A}$. bimaculatus were preyed, representing around $3 \%$ of the initial shoal size. After the recognition period, prey were transferred to the experimental units (rectangular aquariums) containing dechlorinated water (temperature $\sim 25^{\circ} \mathrm{C}$; turbidity $\sim 2 \mathrm{NTU}$ ), where they remained in shoals of ten fish for 48 hours to acclimatise to the experimental conditions. Prey were fed twice daily, they were fed around 10 hours before the experiment, to prevent food from affecting their metabolisms. The piscivores were kept in separate 10001 tanks and were fed until the beginning of the experimental period to prevent predation of $A$. bimaculatus during the experiments.

Each experimental unit was filled with 251 of dechlorinated water (temperature $\sim 25{ }^{\circ} \mathrm{C}$; Turbidity $\sim 2$ NTU). One hour before the beginning of the experiment, the experimental units labelled as turbid water received 10 1 of water with 60 grams of clay dissolved in it, generating an average turbidity of 120 NTU and maximum depth range of light of $7 \mathrm{~cm}$ (as determined using a Secchi Disk). Clear water treatments received the same amount of water (but without clay) to standardise the disorder caused by water entering the tanks.

The experimental period began with the introduction of one piscivore into each experimental unit, totalizing 12 piscivores per species, which were used just once in the experiments. After one hour of interaction, piscivores and prey were separated. Treatments without piscivores (control) also lasted 1 hour. Prey from all treatment combinations were removed from the experimental unit using a fish net; they were anaesthetised by being placed in a container containing $80 \mathrm{mg} / \mathrm{l}$ of benzocaine water solution (GoNTIJO et al., 2003; SANCHES et al., 2015). Blood was removed from fish through cutting the caudal peduncle, using capillary tubes with heparin. Due to the low volume of blood in the prey, blood from all members of the shoal was grouped to examine the physiological responses of the shoal in each experimental unit. This blood was then centrifuged (3000 g per 10 minutes) and the collected plasma transferred to tubes with a lid and frozen for later analysis. Plasma cortisol levels were determined using a commercial ELISA kit (enzymelinked immunosorbent assay kit - cortisol test, intra assay variation of $14 \%$, inter assay variation of $6 \%$ ) according to procedures validated for fish (SINK et al., 2008; BARCELLOS et al., 2010). Three cortisol samples were removed from subsequent data analysis (one from the clear water treatment without predators and two from the turbid water treatment without predators) because their cortisol concentrations were much higher than the standard curve range suggested by the ELISA kit. Plasma glucose levels were evaluated via the Trinder colorimetric method (TRINDER, 1969). All analyses were conducted in duplicate.
Data analysis. To test our predictions we performed two-way analysis of variance (ANOVA) on glucose data, and the Scheirer-Ray-Hare extension of the Kruskal Wallis test (as suggested by SoKaL \& RoHLF, 1995) to analyse the non-parametric variance of cortisol data, since the latter did not meet assumptions of normality and homoscedasticity. In both analyses, plasma cortisol and glucose levels were considered response variables, 'predator regime' (three levels: no predator, with $H$. aff. malabaricus and with $A$. crassipinnis) and 'turbidity' (two levels: clear water and turbid water) were considered independent variables. When significant main effects or interactions were revealed in ANOVA and in Kruskal-Wallis test, Tukey's and Nemenyi's test were respectively done for post-hoc multiple comparisons. All tests were performed using a significance level of $P<0.05$ in the Statistica 7.1® software (STATSOFT, 2005).

\section{RESULTS}

Plasma cortisol levels significantly differed according to the predator regime $\left(H_{2,33}=18.55 ; P<0.01\right)$. When faced with piscivorous fish, regardless of their hunter strategy, plasma cortisol levels in A. bimaculatus shoal members increased by $90 \%$ on average, from $28.2 \mathrm{ng} / \mathrm{ml}$ in the absence of predators to $51.2 \mathrm{ng} / \mathrm{ml}$ with predators present (grouping the data from both predation treatments). We observed that the sit-and-wait piscivore ( $H$. aff. malabaricus) remained motionless for most of the experimental period, causing the prey fish shoal members to remain on the opposite side of the tank in a surveillance state, largely immobile. In contrast, $A$. crassipinnis moved frequently around the aquarium, causing the shoal of prey to swim in the opposite direction, keeping as far as possible from the predator. Despite these differences in predator activity, post-hoc comparisons did not evidence significant differences between the two hunting strategy treatments: with $H$. aff malabaricus ('Mean' $51.9 \pm$ 'Standard Deviation' $12.1 \mathrm{ng} /$ $\mathrm{ml}$ ) and with $A$. crassipinnis $(50.4 \pm 10.6 \mathrm{ng} / \mathrm{ml})$ (Fig. 1).

Plasma cortisol levels were not significantly influenced by water transparency condition $\left(H_{1,33}=0.31\right.$; $P=0.58$ ). Plasma cortisol level was $41.6 \pm 12.3 \mathrm{ng} / \mathrm{ml}$ in clear water and $48.4 \pm 15.8 \mathrm{ng} / \mathrm{ml}$ in turbid water. The interaction between water transparency and predator regime was not significant to determine the plasma cortisol levels $\left(H_{2,33}=0.67 ; P=0.41\right.$; Fig. 1$)$.

In contrast, plasma glucose levels in A. bimaculatus did not change significantly among the treatments of predator regime $\left(F_{2,36}=0.26 ; P=0.77\right)$, nor in response to different water turbidity conditions $\left(F_{1,36}=1.24 ; P=0.27\right)$. The mean glucose level was $33.7 \pm 8.3 \mathrm{mg} / \mathrm{dl}$ without predator, $32.6 \pm$ $13.0 \mathrm{mg} / \mathrm{dl}$ with $H$. aff malabaricus and with $A$. crassipinnis $30.5 \pm 11.8 \mathrm{mg} / \mathrm{dl}$. The mean glucose level was $34.6 \pm 8.7$ $\mathrm{mg} / \mathrm{dl}$ in clear water treatments and $30.3 \pm 13.0 \mathrm{mg} / \mathrm{dl}$ in turbid treatments (Fig. 2). 


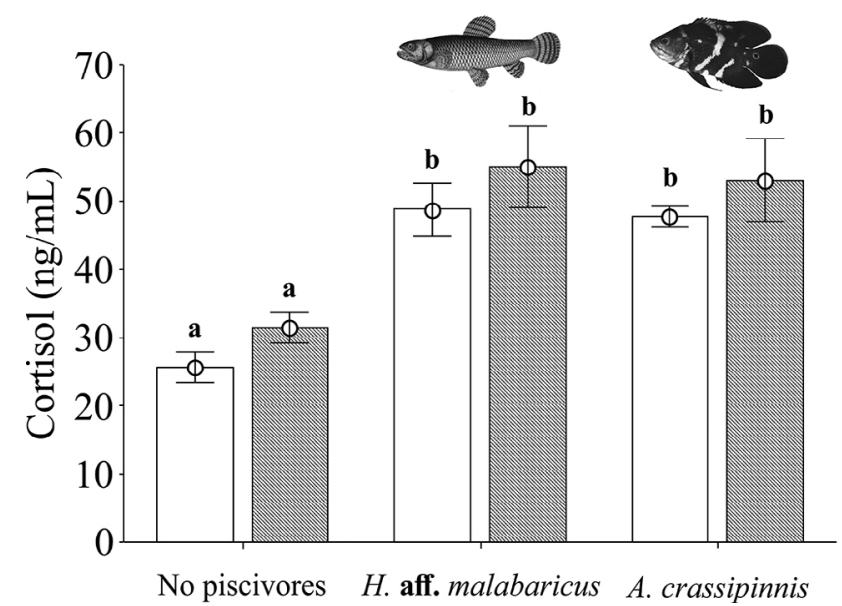

Fig. 1. Mean and standard error of plasma cortisol levels for Astyanax bimaculatus (Linnaeus, 1758) shoals in treatments with clear (white box) and turbid water (striped box). Different letters above bars indicate significant differences at $P<0.05$ in the Kruskal Wallis test between predator types. There were no differences between plasma cortisol levels in clear and turbid water treatments.

\section{DISCUSSION}

The A. bimaculatus shoals, when confronted with piscivorous fish, increased their plasma cortisol levels. This endocrine change occurred in both clear and turbid water conditions, indicating that $A$. bimaculatus responds physiologically to the presence of predators, regardless of the latter's behaviour or the degree of underwater visibility. However, no significant changes in plasma glucose levels were registered in any treatment combination. As cortisol levels may be interpreted as an indication of primary responses to stress, and glucose levels secondary responses (BARTON, 2002), these results suggest that the presence of predators triggered only primary responses in the prey fish. This finding is likely related to the non-consumptive effects of piscivore presence (RIPPLE \& BESCHTA, 2004), because no actual predation took place during the experiment.

The absence of changes in plasma glucose levels indicates that the stress caused by the presence of piscivorous predators was not sufficient to trigger a metabolic response in the prey fish shoals. Alternatively, the experimental period may not have been sufficiently long in terms of the interaction between predator and prey. However, this second hypothesis may be easily refuted considering the results reported in other studies. For example, primary responses and no secondary responses were also recorded in Nile tilapia [Oreochromis niloticus (Linnaeus, 1758)] in an experiment that lasted four times longer than that presented here (SANCHES et al., 2015). It is thus more likely that the absence of changes in glucose levels is a result of the prey's ability to recognise the degree of danger, considering that no conspecific was eaten. Learning takes place more frequently if prey have experienced similar situations that have not resulted in injury (Lima \& Dill, 1990; BARCELlos et al., 2010). The zebrafish [Danio rerio (Hamilton, 1822)], for example, is known to be able to learn about dangerous

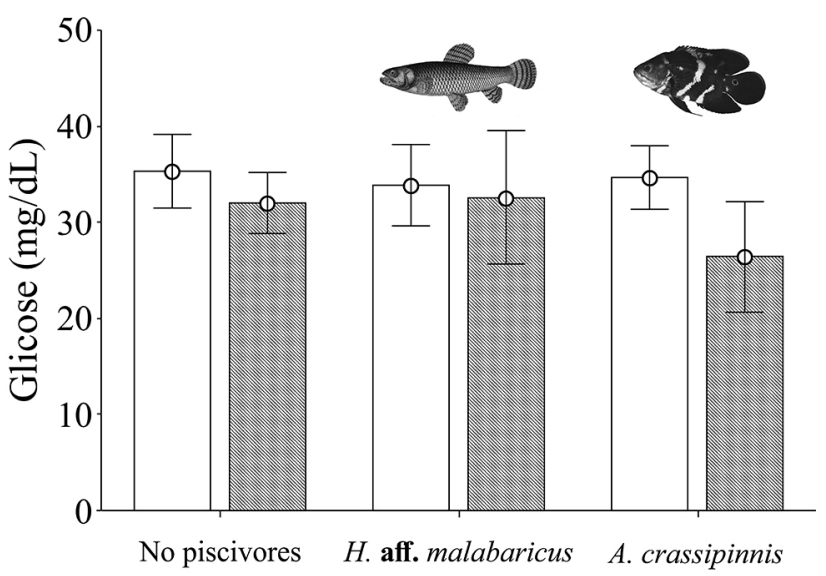

Fig. 2. Mean and standard error of plasma glucose levels for Astyanax bimaculatus (Linnaeus, 1758) shoals in treatments with clear (white box) and turbid water (striped box). Predator regime treatments are specified in ' $x$ ' axis. Plasma glucose levels did not change significantly among the treatments of predator regime, nor in response to different water turbidity conditions.

situations and does not present high levels of cortisol after prolonged visual contact with piscivorous fish (BARCELLOS et al., 2007; 2010). The guppy (Poecilia reticulata Peters, 1859) also exhibits lower cortisol levels based on chemical cues to such predators (Fischer et al., 2014). Therefore, one can consider the existence of an adaptive mechanism that allows fish to assess the degree of predation threat and maintain as near a normal metabolic state as possible.

Prey fish shoal alter its behaviour according to piscivores activity, they remain on the opposite side of the tank in the presence of a motionless sit-and-wait piscivore $(H$. aff. malabaricus), while they swam to keep as far as possible from the active piscivore (A. crassipinnis). However, even though the sit-and-wait and active pursuit strategies caused different behavioural responses in the prey fish (PECKARSKY \& MCINTOSH, 1998; GUARIENTO et al., 2014), such behavioural changes did not result in different metabolic changes. Here A. bimaculatus responded in a physiologically similar manner to the presence of both types of predator, even when forced to adjust their behaviour according to the predators' hunting strategies. Similar results have been reported for P. reticulata (Kolluru et al., 2015) and Brachyrhaphis episcopi (Steindachner, 1878) (ARCHARD et al., 2012), with no clear relationship observed between hormone levels and anti-predator behaviour.

Plasma cortisol and glucose levels in the $A$. bimaculatus shoals were similar in clear and turbid water, indicating that this species is able to recognise a potential predation threat through non-visual cues (BARBOSA \& Castellanos, 2005; Figueiredo et al., 2015). Therefore, while increased turbidity may provide a visual refuge for prey (RANÅKER et al., 2012), it does not interfere with their ability to recognise potential predators through non-visual senses, such as chemical cues. Similar results have been observed in guppies, with cortisol levels not varying under 
low and high luminosity conditions in populations subjected to a predation threat (KoLluru et al., 2015).

Lastly, based on our findings we suggest that physiological changes in prey fish such as A. bimaculatus are more related to their ability to recognise and appropriately respond to the current degree of danger. As such, the type of anti-predation behaviour displayed due to variation in piscivore hunting mode and water transparency conditions is of minor importance in determining plasma cortisol and glucose levels. The ability to perceive the environment through non-visual cues allows the minimisation of the nonlethal effects of predation - in the present study reflected by the absence of secondary physiological changes - enabling prey to maintain a largely stable homeostatic state when faced with possible predators.

Acknowledgments. We express our gratitude to Nupélia (Núcleo de Pesquisas em Limnologia, Ictiologia e Aquicultura) for financial and logistical support. We thank L. A. Lolis for support during the fieldwork and the experimental period. Finally, we thank C. B. R. Martinez for critically reading this manuscript. We highlight that our experiment was carried out in accordance with the "Ethical Principles in Animal Research" adopted by the Brazilian College of Animal Experimentation (COBEA).

\section{REFERENCES}

Abujanra, F.; Agostinho, A. A. \& Hahn, N. S. 2009. Effects of the flood regime on the body condition of fish of different trophic guilds in the Upper Paraná River floodplain, Brazil. Brazilian Journal of Biology 69:469-479.

Ajemian, M. J.; Sohel, S. \& Mattila, J. 2015. Effects of turbidity and habitat complexity on antipredator behavior of three-spined sticklebacks (Gasterosteus aculeatus). Environmental Biology of Fishes 98:45-55.

Archard, G. A.; Earley, R. L.; Hanninen, A. F. \& Braithwaite, V. A. 2012 Correlated behaviour and stress physiology in fish exposed to different levels of predation pressure. Functional Ecology 26:637-645.

Barbosa, P. \& Castellanos, I. 2005. Ecology of Predator-Prey Interactions. Oxford, Oxford University Press, 394p.

Barcellos, L. J. G.; Marqueze, A.; Trapp, M.; Quevedo, R. M. \& FERreirA, D. 2010. The effects of fasting on cortisol, blood glucose and liver and muscle glycogen in adult jundiá Rhamdia quelen. Aquaculture 300:231-236.

Barcellos, L. J. G.; Ritter, F.; Kreutz, L. C.; Quevedo, R. M.; Silva, L. B.; Bedin, A. C. Finco, J. \& Cericato, L. 2007. Whole-body cortisol increases after direct and visual contact with a predator in zebrafish, Danio rerio. Aquaculture 272:774-778.

Barcellos, L. J. G.; Woehl, V. M.; Wassermann, G. F.; Quevedo, R. M.; ItTZÉs, I. \& KrIeGer, M. H. 2001. Plasma levels of cortisol and glucose in response to capture and tank transference in Rhamdia quelen (Quoy e Gaimard), a South American catfish. Aquaculture Research 32:121-123.

Barreto, R. E. \& Volpato, G. L. 2006. Stress responses of the fish Nile tilapia subjected to electroshock and social stressors. Brazilian Journal of Medical and Biological Research 39(12):1605-1612.

Barton, B. A. 2002. Stress in Fishes: A Diversity of Responses with Particular Reference to Changes in Circulating Corticosteroids. Integrative and Comparative Biology 42(3):517-525.

Barton, B. A. \& Iwama, G. K. 1991. Physiological changes in fish from stress in aquaculture with emphasis on the response and effects of corticosteroids. Annual Review of Fish Diseases 1:3-26.

BECKER, L. J. S. \& GABOR, C. R. 2012. Effects of turbidity and visual vs. chemical cues on anti-predator response in the endangered fountain darter (Etheostoma fonticola). Ethology 118:994-1000.

Bell, A. M.; Backström, T.; Huntingford, A. F.; Pottinger, T. G. \& WINBERG, S. 2007. Variable neuroendocrine responses to ecologicallyrelevant challenges in sticklebacks. Physiology and Behavior 91:15-25.
Bendhack, F. \& Urbinati, E. C. 2009. Mitigating stress effects during transportation of matrinxã (Brycon amazonicus Günther, 1869; Characidae) through the application of calcium sulfate. Journal of Applied Ichthyology 25(2):201-205.

BRown, G. E. 2003. Learning about danger: chemical alarm cues and local risk assessment in prey fishes. Fish and Fisheries 4(3):227-234.

De Robertis, A.; Ryer, C. H.; Veloza, A. \& Brodeur, R. D. 2003. Differential effects of turbidity on prey consumption of piscivorous and planktivorous fish. Canadian Journal of Fisheries and Aquatic Sciences 60:1517-1526.

Ferrari, M. C. O.; LysaK, K. R. \& Chivers, D. P. 2010. Turbidity as an ecological constraint on learned predator recognition and generalization in a prey fish. Animal Behaviour 79:515-519.

Ferrari, M. C. O.; Messier, F. \& Chivers, D. P. 2008. Can prey exhibit threat-sensitive generalization of predator recognition? Extending the Predator Recognition Continuum Hypothesis. Proceedings of the Royal Society 275:1811-1816.

Figueiredo, B. R. S.; Mormul, R. P. \& Benedito, E. 2015. Structural complexity and turbidity do not interact to influence predation rate and prey selectivity by a small visually feeding fish. Marine and Freshwater Research 66:170-176.

Figueiredo, B. R. S.; Mormul, R. P.; Chapman, B. B.; Lolis, L. A.; Fiori, L. F. \& BenEDito, E. 2016. Turbidity amplifies the non-lethal effects of predation and affects the foraging success of characid fish shoals. Freshwater Biology 61:293-300.

Fischer, E. K.; Harris, R. M.; Hofmann, H. A. \& Hoke, K. L. 2014. Predator exposure alters stress physiology in guppies across timescales. Hormones and Behavior 64:165-172.

Flodmark, L. E. W.; Urke, H. A.; Halleraker, J. H.; Arnekleiv, J. V.; Vøllestad, L. A. \& Poléo, A. B. S. 2002. Cortisol and glucose responses in juvenile brown trout subjected to a fluctuating flow regime in an artificial stream. Journal of Fish Biology 60:238-248.

Gealh, A. M. \& Hahn, N. S. 1998. Alimentação de Oligosarcus longirostris Menezes e Gèry (Osteichthyes, Acestrorhynchinae) do reservatório de Salto Segredo, Paraná, Brasil. Revista Brasileira de Zoologia 15(4):985-993.

Gontijo, A. M. M. C.; Barreto, R. E.; Speit, G.; Reyes, V. A. V. R.; Volpato, G. L. \& SalVAdori, D. M. F. 2003. Anesthesia of fish with benzocaine does not interfere with comet assay results. Mutation Research 534:165-172.

Guariento, R. D.; Luttbeg, B.; Mehner, T. \& Esteves, F. A. 2014. The effect of predation pressure and predator adaptive foraging on the relative importance of consumptive and non-consumptive predator net effects in a freshwater model system. Oikos 123:705-713.

Hahn, N. S.; Fugi, R. \& Andrian, I. F. 2004. Trophic ecology of the fish assemblages. In: Thomaz, S. M.; Agostinho, A. A. \& Hahn, N. S. eds. The Upper Paraná River and its floodplain: Physical Aspects, Ecology and Conservation. Leiden, Backhuys Publishers, p. 247-269.

Hoeinghaus, D. J. \& Pelicice, F. M. 2010. Lethal and nonlethal effects of predators on stream fish species and assemblages: A synthesis of predation experiments. In: GIDO, K. B. \& JACKSON, D. A. eds. Community ecology of stream fishes: concepts, approaches, and techniques. Bethesda, American Fisheries Society 73, p. 619-648.

Hoshiba, M. A.; Gonçalves, F. D. \& Urbinati, E. C. 2009. Respostas fisiológicas de estresse no matrinxã (Brycon amazonicus) após exercício físico intenso durante a captura. Acta Amazonica 39(2):445-452.

Julio JR, H. F.; Tós, C. D.; Agostinho, A. A. \& Pavanelli, C. S. 2009. A massive invasion of fish species after eliminating a natural barrier in the upper rio Paraná basin. Neotropical Ichthyology 7(1):709-718.

Koakoski, G.; Oliveira, T. A.; Rosa, J. G. S.; Fagundes, M.; Kreutz, L. C. \& Barcellos, L. J. G. 2012. Divergent time course of cortisol response to stress in fish of different ages. Physiology \& Behavior 106:129-132.

Kolluru, G. R.; Walz, J.; Hanninen, A. F.; Downey, K.; Kalbach, B.; GuPTA, S. \& EARLEY, R. L. 2015. Exploring behavioral and hormonal flexibility across light environments in guppies from low-predation populations. Behaviour 152:963-993.

Kovalenko, K. E.; Dibble, E. D.; Agostinho, A. A. \& Pelicice, F. M. 2010. Recognition of non-native peacock bass, Cichla kelberi by native prey: testing the naiveté hypothesis. Biological Invasions 12:3071-3080. 
Lima, S. L. 1998. Nonlethal effects in the ecology of predator-prey interactions. Bioscience 48:25-34.

Lima, S. L. \& Dill, L. M. 1990. Behavioral decisions made under the risk of predation: a review and prospectus. Canadian Journal of Zoology 68(4):619-640.

LINK, J. S. \& GARRISON, L. P. 2002. Changes in piscivory associated with fishing induced changes to the finfish community on Georges Bank. Fisheries Research 55:71-86.

MartíneZ-Porchas, M.; MartíneZ-CóRdova, L. R. \& Ramos-EnRIQUEZ, R. 2009. Cortisol and glucose: Reliable indicators of fish stress? PanAmerican Journal of Aquatic Sciences 4(2):158-178.

Montenegro, A. K. A.; Vieira, A. C. B; Cardoso, M. M. L.; Souza, J. E. R. T.; CRISPIM, M. C. 2013. Piscivory by Hoplias aff. malabaricus (Bloch, 1794): A question of prey availability? Acta Limnologica Brasiliensia 25(1):68-78.

Moustahfid, H.; Tyrrell, M. C.; Link, J. S.; Nye, J. A.; SMith, B. E. \& GambLE, R. J. 2010. Functional feeding responses of piscivorous fishes from the northeast US continental shelf. Oecologia 163:1059-1067.

Peckarsky, B. L. \& McIntosh, A. R. 1998. Fitness and community consequences of avoiding multiple predators. Oecologia 113:565-576.

Petry, A. C.; Gomes, L. C.; Piana, P. A. \& Agostinho, A. A. 2010. The role of the predatory trahira (Pisces: Erythrinidae) in structuring fish assemblages in lakes of a Neotropical floodplain. Hydrobiologia 651:115-126

RANÅKeR, L.; NilsSON, P. A. \& BRÖNMARK, C. 2012. Effects of degraded optical conditions on behavioural responses to alarm cues in a freshwater fish. PlosOne 7(6):e38411.

Rehnberg, B. G.; Smith, R. J. F. \& Sloley, B. D. 1987. The reaction of pearl dace (Pisces, Cyprinidae) to alarm substance: time-course of behavior, brain amines, and stress physiology. Canadian Journal of Zoology 65:2916-2921.

ReID, S. G.; BernIE, N. J. \& PerRY, S. F. 1998. The adrenergic stress response in fish: Control of catecholamine storage and release. Comparative Biochemistry and Physiology 120C:1-27.

RipPle, W. J. \& Beschta, R. L. 2004. Wolves and the ecology of fear: can predation risk structure ecosystems. Bioscience 54(8):755-766.
Roberto, M. C.; Santana, N. F. \& Thomaz, S. M. 2009. Limnology in the Upper Paraná River floodplain: large-scale spatial and temporal patterns, and the influence of reservoirs. Brazilian Journal of Biology 69:717-725.

Ruane, N. M.; Wendelaar, B. S. E. \& Balm, P. H. M. 1999. Differences between rainbow trout and brown trout in the regulation of the pituitaryinterrenal axis and physiological performance during Confinement. General and Comparative Endocrinology 115:210-219.

Sanches, F. H. C.; Miyal, C. A.; Pinho-Neto, C. F. \& Barreto, R. E. 2015. Stress responses to chemical alarm cues in Nile tilapia. Physiology \& Behavior 149:8-13.

Sink, T. D.; Lochmann, R. T. \& Fecteau, K. A. 2008. Validation, use, and disadvantages of enzyme-linked immunosorbent assay kits for detection of cortisol in channel catfish, largemouth bass, red pacu, and golden shiners. Fish Physiology Biochemistry 34:95-101.

SoKal, R. R. \& RohlF, F. J. 1995. Biometry: The Principles and Practice of Statistics in Biological Research. 3ed. New York, W. H. Freeman and Co. 887p.

Statsoft, Inc. Satistica. 2005. Data Analysis Software System. Version 7.1 for Windows. Tulsa: Statsoft. Inc.

Thompson, R. M.; Beardall, J.; Beringer, J.; Grace, M. \& Sardina, P. 2013. Means and extremes: building variability into community-level climate change experiments. Ecology Letters 16:799-806.

Trenberth, K. E.; Jones, P. D.; Ambenje, P.; Bojariu, R.; Easterling, D. \& KLeIN TANK, A. 2007. Climate change 2007: the physical science basis. In: Solomon, S.; Qin, D.; Manning, M.; Chen, Z.; Marquis, M.; Averyt, K. B.; Tignor, M. \& Miller, H. L. eds. Contribution of working group $I$ to the fourth assessment report of the intergovernmental panel on climate change. Cambridge, Cambridge University Press, p. 235-336.

TRINDER, P. 1969. Determination of Glucose in Blood Using Glucose Oxidase with an Alternative Oxygen Acceptor. Annals Clinical Biochemistry 6(1):24-27.

Werner, E. E. \& Peacor, S. D. 2006. Lethal and nonlethal predator effects on an herbivore guild mediated by system productivity. Ecology 87:347-361. 